\title{
A PHYLOGENETIC ANALYSIS OF THE GENUS PLEUROTHALLIS, WITH EMPHASIS ON PLEUROTHALLIS SUBSECTION MACROPHYLLAE- FASCICULATAE, USING NUCLEAR ITS AND CHLOROPLAST DNA SEQUENCING
}

\author{
M. Wilson* , C. Belle, A. Dang, P. Hannan, C. Kenyon, \\ H. Low, T. Stayton \& M. Woolley \\ Biology Department, The Colorado College, Colorado Springs, CO 80903, USA \\ * Corresponding author: mwilson@coloradocollege.edu
}

Several revisions of the genus Pleurothallis have been proposed. Luer has proposed that Pleurothallis species in subgenus Scopula be segregated into the genera Colombiana and Ancipitia. Szlachetko and Margonska (2001) proposed the genus Zosterophyllanthos for Pleurothallis subsection Macrophyllae-Fasciculatae. As an alternative, Luer (2005) proposed the genus Acronia by uniting Pleurothallis subsection Macrophyllae-Fasciculatae with subsections Acroniae and Amphygiae. The molecular phylogenetic studies by Pridgeon and Chase (2001), however, suggested that these taxonomic revisions might not be justified. We report here a more detailed phylogenetic analysis of the genus Pleurothallis, with emphasis on subsection Macrophyllae-Fasciculatae, with data primarily from nuclear ITS sequencing, supplemented with preliminary data from plastid DNA (rpoB2, rpoC1, and ycfl) sequencing. Some initial, tentative conclusions can be drawn. In the strict consensus maximum-parsimony tree of ITS data, many of the clades collapse, leaving a polytomy with a single, highly supported node that tentatively could be used to delimit the genus Pleurothallis. Such a tree would argue for an expanded concept of the genus Pleurothallis, in which the groups Ancipitia, Colombiana, and Acronia/Zosterophyllanthos, if shown to be monophyletic, are relegated to subgenera. 